\title{
Differential Effects of NGF and BDNF on Voltage-Gated Calcium Currents in Embryonic Basal Forebrain Neurons
}

\author{
Eric S. Levine,' Cheryl F. Dreyfus, ${ }^{1}$ Ira B. Black, ${ }^{1}$ and Mark R. Plummer ${ }^{2}$ \\ ${ }^{1}$ Department of Neuroscience and Cell Biology, UMDNJ/Robert Wood Johnson Medical School, Piscataway, New \\ Jersey 08854 and ${ }^{2}$ Department of Biological Sciences, Rutgers-The State University, Piscataway, New Jersey \\ 08855-1059
}

\begin{abstract}
A number of studies have begun to describe the effects of nerve growth factor (NGF) and the closely related brainderived neurotrophic factor (BDNF) on the function of basal forebrain neurons. Little is known, however, about the effects of neurotrophins on membrane calcium conductances, which may play a role in growth factor signal transduction as well as regulation of neuronal excitability. Using the whole-cell patch-clamp technique, we investigated the effects of both NGF and BDNF on voltage-gated $\mathrm{Ca}^{2+}$-channel currents in cultured embryonic basal forebrain neurons. Exposure for 4-6 d to NGF significantly increased both the L-type and N-type components of the whole-cell current. Conversely, similar exposure to BDNF had no effect on $\mathrm{Ca}^{2+}$-channel currents. Consequently, one of the important effects of NGF may be to enhance calcium entry via voltage-dependent channels.
\end{abstract}

[Key words: neurotrophin, calcium, NGF, brain-derived neurotrophic factor, basal forebrain, patch clamp]

Nerve growth factor (NGF) and other members of the neurotrophin gene family have well-characterized effects on the survival and function of many neuronal populations (Levi-Montalcini and Angeletti, 1968; Thoenen et al., 1987). In the basal forebrain, these factors modulate transmitter metabolism (Hefti et al., 1985; Friedman et al., 1993), and can prevent cell death after injury or axotomy (Hefti, 1986; Williams et al., 1986). Since basal forebrain neurons degenerate in Alzheimer's disease, neurotrophin effects on these cells could have relevance for this disease.

The signal transduction pathways activated by the neurotrophins have bcen extensively studied in PC-12 cells, a pheochromocytoma cell line that differentiates into a sympathetic neuron-like phenotype in response to NGF (Greene and Tischler, 1976). In these cells, NGF elicits a range of second-messenger responses, including increases in cyclic adenosine monophosphate, cyclic guanosine monophosphate, calcium, and phosphoinositide turnover (Contreras et al., 1987; Nikodijevic and Guroff, 1991). Growth factor signal transduction also involves activation of the protein kinases Src and Raf, as well as the GTP-

Received June 20, 1994; revised Oct. 20, 1994; accepted Oct. 31, 1994

We thank Dr. Robin Davis for review of this manuscript. This work was supported by an NICHD Grant (HD 23315) to I.B.B., a National Research Service Award (NS 09137-02) to E.S.L., and a Grant in Aid (\#93-G53) from the American Heart Association to M.R.P.

Correspondence should be addressed to Eric S. Levine, Department of Neuroscience and Cell Biology, UMDNJ/Robert Wood Johnson Medical School, 675 Hoes Lane, Piscataway, NJ 08854.

Copyright (C) 1995 Society for Neuroscience $0270-6474 / 95 / 153084-08 \$ 05.00 / 0$ binding protein Ras (D'Arcangelo and Halegoua, 1993). In addition, NGF induces the expression of voltage-dependent sodium and calcium channels in PC-12 cells (Garber et al., 1989; Plummer et al., 1989; Kalman et al., 1990).

Calcium may be a critical second messenger, mediating a variety of growth factor effects. Basic fibroblast growth factor (bFGF), for example, increases L-type calcium currents in ventromedial hypothalamic neurons (Koike et al., 1993) and in retinal glial cells (Puro and Mano, 1991). Further, the mitogenic actions of bFGF on these glial cells can be blocked by specific calcium channel antagonists (Puro and Mano, 1991). The effects of NGF on sympathetic neuron process outgrowth may also involve calcium (Rogers and Hendry, 1990). In addition, brainderived neurotrophic factor (BDNF) and neurotrophin-3 (NT-3) increase intracellular calcium concentration in cultured cortical neurons (Berninger et al., 1993).

Despite some evidence for a role of calcium in trophic actions, little is known about the effects of the neurotrophins on calcium currents. The present studies, therefore, examined the effects of NGF and BDNF on the voltage-gated calcium conductance in cultured basal forebrain neurons. Exposure to NGF, but not exposure to BDNF, increased the calcium current density in these neurons. This increase reflected changes in both the L-type and $\mathrm{N}$-type components of the high-threshold calcium current, as well as a dihydropyridine-insensitive, $\omega$ - conotoxin-insensitive component of current. Consequently, calcium entry via these voltage-dependent channels may mediate some of the important neurotrophic effects of NGF.

\section{Materials and Methods}

Tissue dissociation and cell culture. Basal forebrains were obtained from embryonic day 17 Sprague-Dawley rats. Time-mated pregnant rats were killed by $\mathrm{CO}_{2}$ asphyxiation. Fetuses were removed by caesarean section and transferred to a sterile petri dish with phosphate-buffered saline. Fetal basal forebrains were dissected from surrounding brain tissue and meninges were completely removed. Pooled tissue from 12 litters was mechanically dissociated in $2 \mathrm{ml}$ of nutrient medium. Cells were counted and plated on poly-b-lysinc-coated petri dishes at a final density of $10^{6}$ cells/dish.

Cultures were maintained in serum-free medium (SFM) at $37^{\circ} \mathrm{C}$ in a $95 \%$ air $/ 5 \% \mathrm{CO}_{2}$ humidified incubator. SFM consisted of a $1: 1(\mathrm{v} / \mathrm{v})$ mixture of Ham's F-12 and Eagle's minimum essential medium and supplemented with insulin $(25 \mathrm{mg} / \mathrm{ml})$, transferrin $(100 \mathrm{mg} / \mathrm{ml})$, putrescine $(60 \mathrm{~mm})$, progesterone $(20 \mathrm{nM})$, selenium $(30 \mathrm{nM})$, glucose $(6$ $\mathrm{mg} / \mathrm{ml})$, and penicillin-streptomycin $(0.5 \mathrm{U} / \mathrm{ml}, 0.5 \mathrm{mg} / \mathrm{ml}$, respectively). These cultures contained virtually pure neurons, as judged by neuron-specific enolase immunocytochemistry (Lu et al., 1991). There was, however, a heterogeneous population of neurons in these cultures. In order to somewhat restrict our sample population, we only recorded from cells that had large, pyramidal-shaped cell bodies. 
A

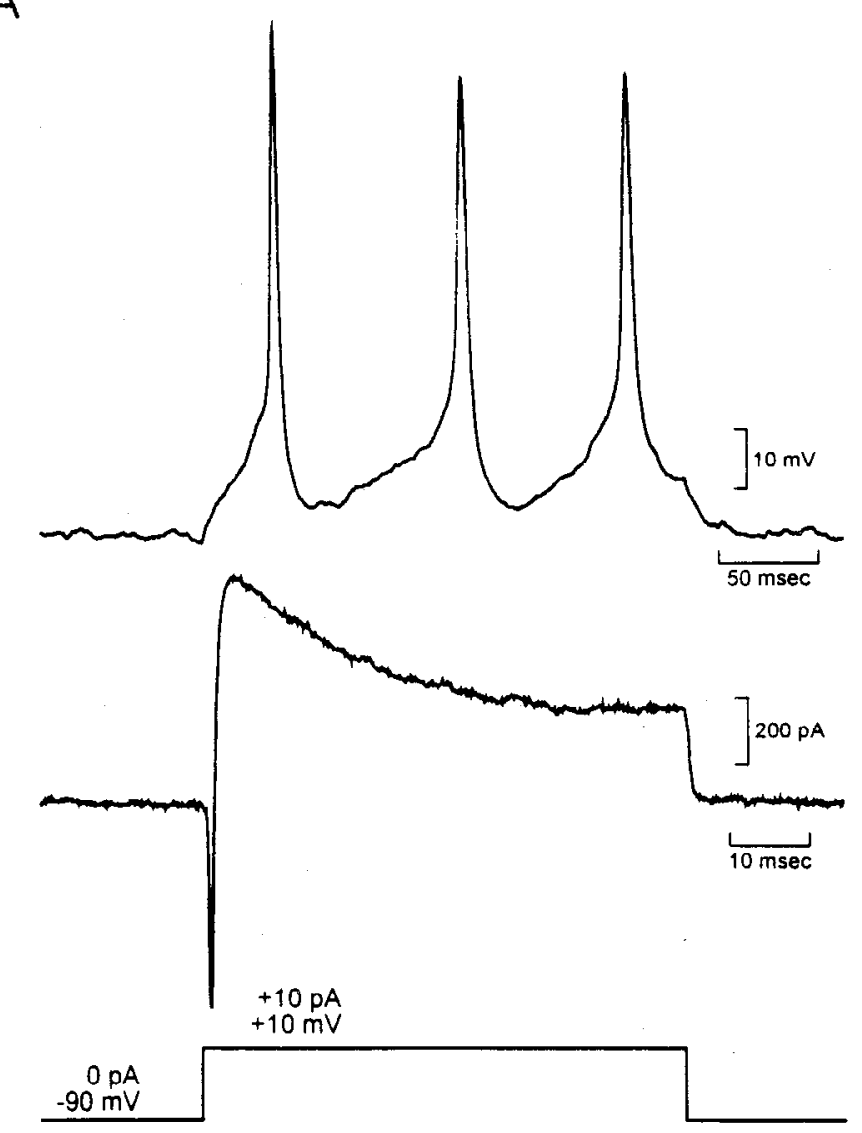

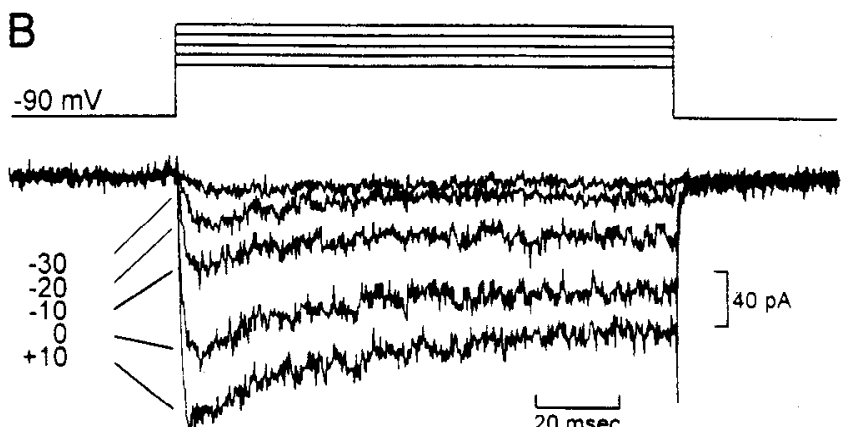

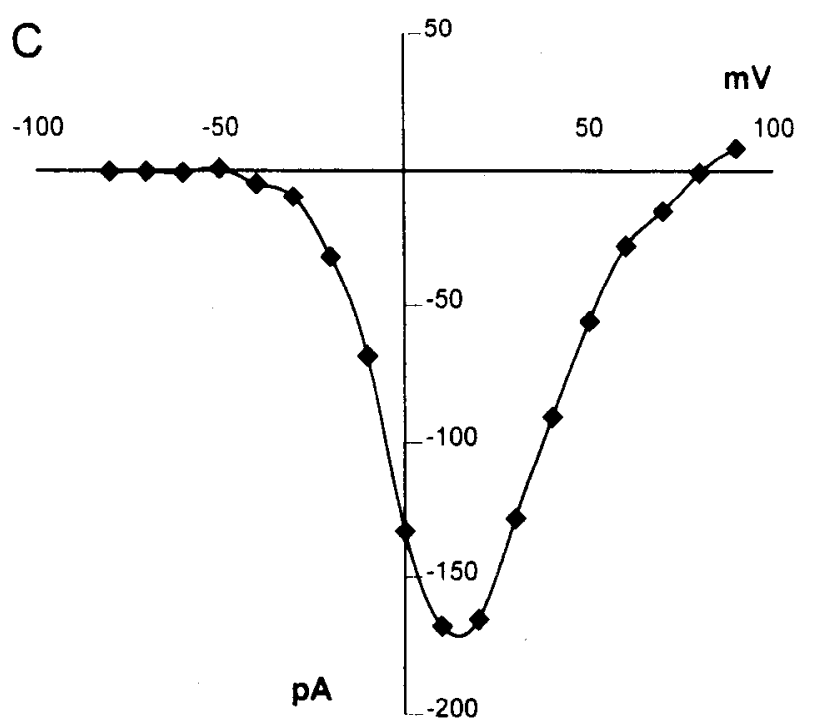

Figure 1. Embryonic basal forebrain neurons grown in serum-free medium showed the characteristic electrophysiological properties of mature neurons. A, Selected sweep from a whole-cell current-clamp recording showing a burst of action potentials elicited by step injection of depolarizing current (top trace). Whole-cell voltage-clamp recording shows transient inward current followed by multiple components of outward current following step depolarization (middle trace). Bottom trace shows stimulus protocol for both current-clamp and voltage-clamp recordings. $B$, Series of sweeps from a whole-cell voltage-clamp recording of voltage-activated $\mathrm{Ca}^{2+}$-channel currents. $\mathrm{Ba}^{2+}(2 \mathrm{mM})$ was the charge carrier. $\mathrm{Both}$ inactivating and maintained components of current were observed. $C$, Current-voltage relationship of experiment illustrated in $B$. Peak current is plotted.

Patch-clamp recordings. Whole-cell recordings were obtained after 4-6 d in vitro with standard techniques (Hamill et al., 1981). The currents were recorded with an Axoclamp 200 amplifier, digitized at 5-20 $\mathrm{kHz}$, with an INDEC IDA 15125 interface, filtered at $5 \mathrm{kHz}$ and stored. Linear leak and capacitative currents (measured with hyperpolarizing pulses of $1 / 10$ the test potential) were subtracted prior to analysis. Recording parameters and stimulus protocols were controlled by custom software written with Borland $\mathrm{C}++$ that utilized device driver libraries supplied by INDEC. Data analysis programs were written with Microsoft Visual Basic. The external bath solution for current- and voltageclamp recordings was (in $\mathrm{mm}$ ) $1.67 \mathrm{Ca}, 1 \mathrm{Mg}, 5.36 \mathrm{~K}, 137 \mathrm{Na}, 17$ glucose, $10 \mathrm{HEPES}$, and 50 sucrose. The pipette solution was (in $\mathrm{mM}$ ) $112 \mathrm{KCl}, 2 \mathrm{MgCl}_{2}, 0.1 \mathrm{CaCl}_{2}, 11$ EGTA, 10 HEPES, and 2 ATP. $\mathrm{Ca}^{2+}$ channel currents werc isolated from other voltage-dependent currents by ionic substitution and addition of sodium and potassium channel blockers, as detailed below. The external bath solution for recording $\mathrm{Ca}^{2+}$-channel currents contained (in mM) $20 \mathrm{Ba}$-acetate, 135 tetraethylammonium-aspartate, 10 HEPES, and 0.001 tetrodotoxin ( $\mathrm{pH} \mathrm{7.5).} \mathrm{The}$ pipette solution contained (in mM) 123 Cs-aspartate, 10 Cs-EGTA, 5 $\mathrm{MgCl}_{2}$, and 4 ATP ( $\mathrm{pH} 7.5$ ). All recordings were made at room temperature. In order to obtain high-quality voltage-clamp recordings, cells were triturated and replated prior to recording.

Data analysis. Following a dissociation, dishes of cells were divided into two sets of sister cultures (approximately 10 dishes/set). As indicated, media containing NGF or BDNF (final concentration, $100 \mathrm{ng} / \mathrm{ml}$ ) was added to one set of dishes and a vehicle control added to the other. Peak current measurements were made with a standard $120 \mathrm{msec}$ depolarizing pulse from a holding potential of either -50 or $-90 \mathrm{mV}$ to a test potential of $+10 \mathrm{mV}$. Cell capacitance was computed by inte- grating current during a capacitative transient and dividing by pulse voltage. Calcium current density was then obtained by dividing peak current by cell capacitance. Current densities were calculated for each of the recordings, and the values from a single set of cells were averaged. The mean current densities from the matched sets were compared statistically using Student's $t$ test.

Drugs. NGF was obtained from Boehringer-Mannheim, BDNF was a gift from Cephalon, $(-)-(R)-202-791$ was a gift from Sandoz, and $\omega-\mathrm{Cg} \mathrm{Tx}$ was obtained from Peptides International.

\section{Results}

\section{Electrophysiology of embryonic basal forebrain neurons}

When grown under serum-free conditions for 4-6 d, cells isolated from the embryonic basal forebrain exhibited the characteristics of fully functional neurons. Resting potentials measured with whole-cell current clamp ranged from -60 to $-80 \mathrm{mV}$, and cells fired overshooting action potentials in response to depolarizing current injection (Fig. 1A, top trace). Spontaneous synaptic potentials were also observed, although they were not characterized in detail. Bath application of glutamate $(10 \mu \mathrm{M})$ elicited action potentials and large depolarizations (not shown). Some cells did display spontaneous firing that appeared to be due to suprathreshold depolarization from synaptic inputs. Whole-cell voltage-clamp recordings showed rapidly inactivat- 


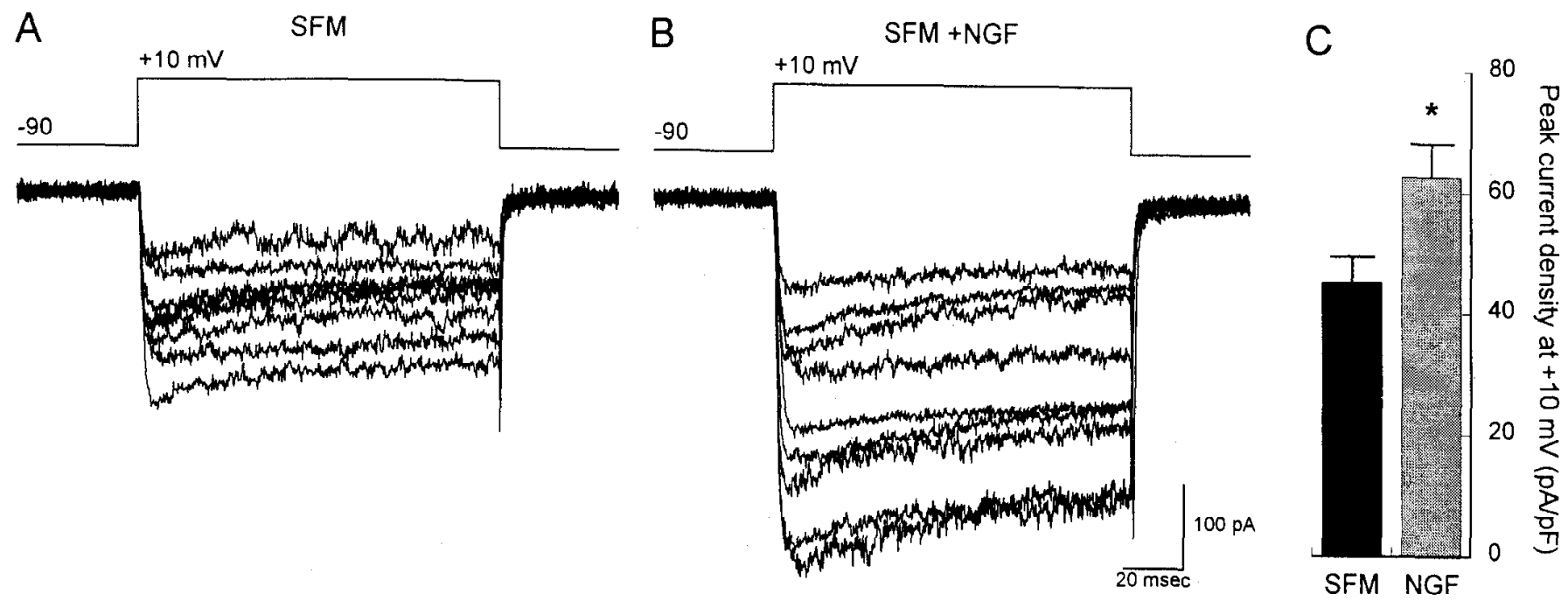

Figure 2. Exposure to NGF increased the magnitude of voltage-activated calcium current. $A$, Superimposed sweeps taken from two sets of cultures grown in serum-free medium. $B$, Superimposed sweeps taken from two sets of cultures grown in media with added NGF Cells were from sister cultures of those shown in $A$. Note that the average magnitude of the current was larger than in $A$. In this and subsequent figures, the voltage protocol is illustrated above the sweeps. Calibration bars apply to both $A$ and $B$. $C$, Overall increase in current density induced by exposure to NGF. Mean \pm SEM. The values for SFM and NGF were significantly different (asterisk; $n=8$ sets of cultures; $p<0.01$, Student's $t$ test).

ing inward currents followed by both maintained and inactivating outward currents (Fig. $1 A$, bottom trace).

When whole-cell voltage-clamp recordings were made with solutions designed to isolate current through voltage-gated calcium channels, only high voltage-activated currents were observed (Fig. $1 B$ ). Both inactivating and noninactivating components were present, which corresponded to L-type, N-type, and a dihydropyridine-insensitive, $\omega$-conotoxin-insensitive type of calcium current (see below). The currents activated at approximately $-40 \mathrm{mV}$ and reversed between +60 and $+80 \mathrm{mV}$ (Fig. 1C). Peak inward current was typically seen at +10 to $+20 \mathrm{mV}$. We therefore used a $+10 \mathrm{mV}$ test potential to compare the current magnitudes of control and neurotrophin-treated cells. In none of our recordings ( $n=130$ cells) were any low voltageactivated (T-type) currents observed.

\section{Effects of NGF}

Neurons grown in the presence of $100 \mathrm{ng} / \mathrm{ml} \mathrm{NGF}$ for $4-6 \mathrm{~d}$ had qualitatively similar properties to those grown under serumfree conditions. The characteristics of the action potentials, firing patterns, and inward and outward currents of the NGF-treated cells were not strikingly different from those of the serum-free cells. In addition, there was no obvious change in cell size or neurite length or complexity. There was, however, a considerable increase in the magnilude of the voltage-gated $\mathrm{Ca}^{2}$-channel currents in the NGF-treated cells when compared to serum-free cells (Fig. 2).

To compare calcium current magnitude in NGF-treated and serum-free cells, peak calcium current was measured with depolarizing pulses to a voltage of $+10 \mathrm{mV}$ from a holding po-

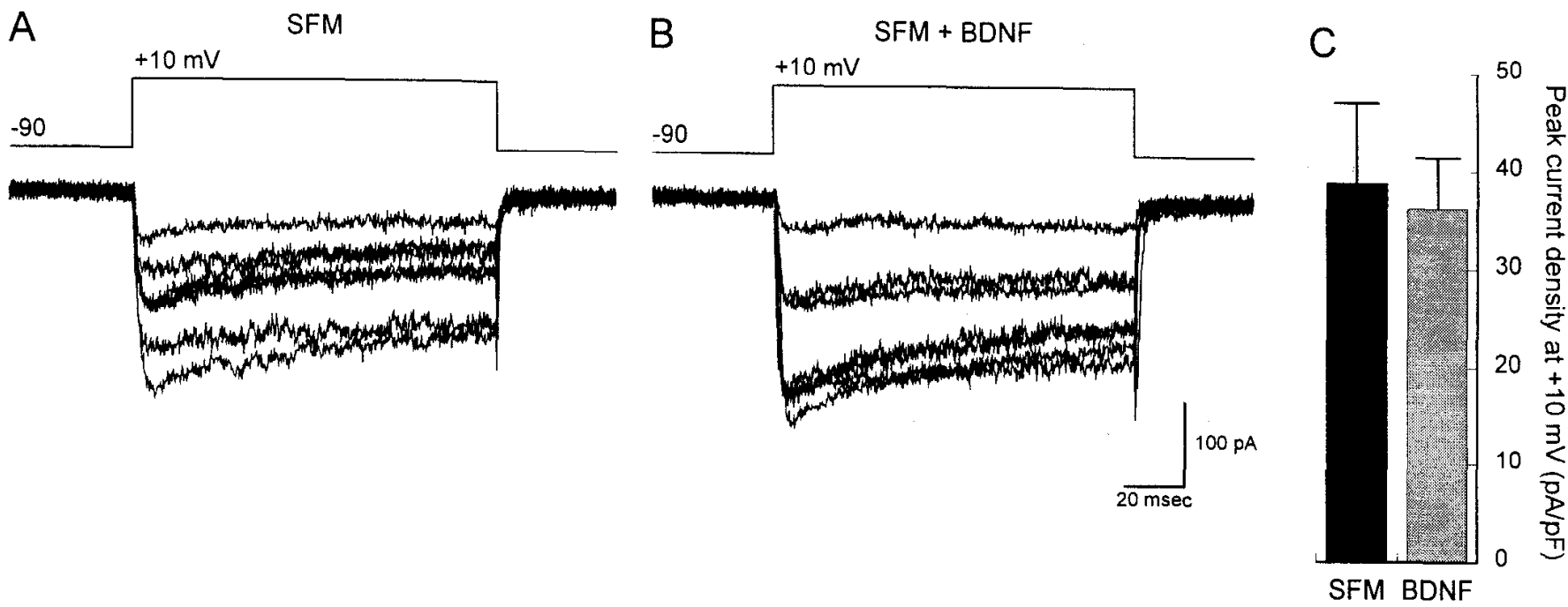

Figure 3. Exposure to BDNF had no effect on the magnitude of voltage-activated calcium current. $A$, Superimposed sweeps taken from two sets of cultures grown in serum-free medium. $B$, Superimposed sweeps taken from two sets of cultures grown in media with added BDNF. Cells were from sister cultures of those shown in $\Lambda$. Note that the avcrage magnitude of the current was similar to that in $A$. Calibration bars apply to both $A$ and $B$. C, Overall calcium current density was not affected by BDNF (mean \pm SEM; $n=5$ sets of cultures; $p>0.6$, Student's $t$ test). 
A

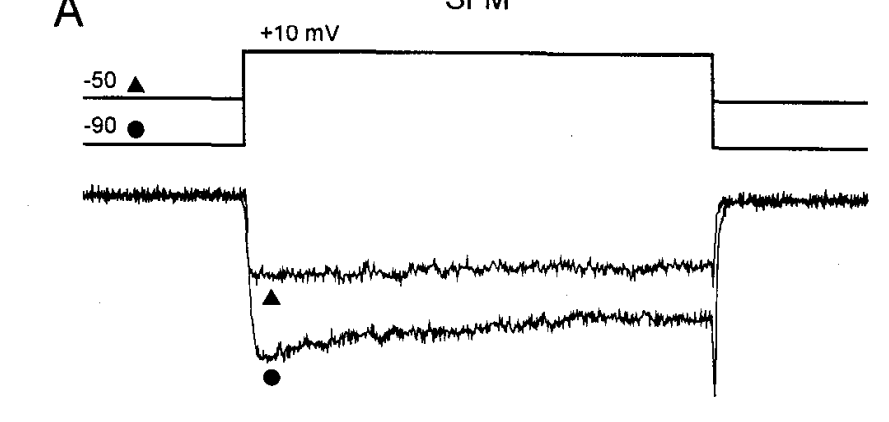

B

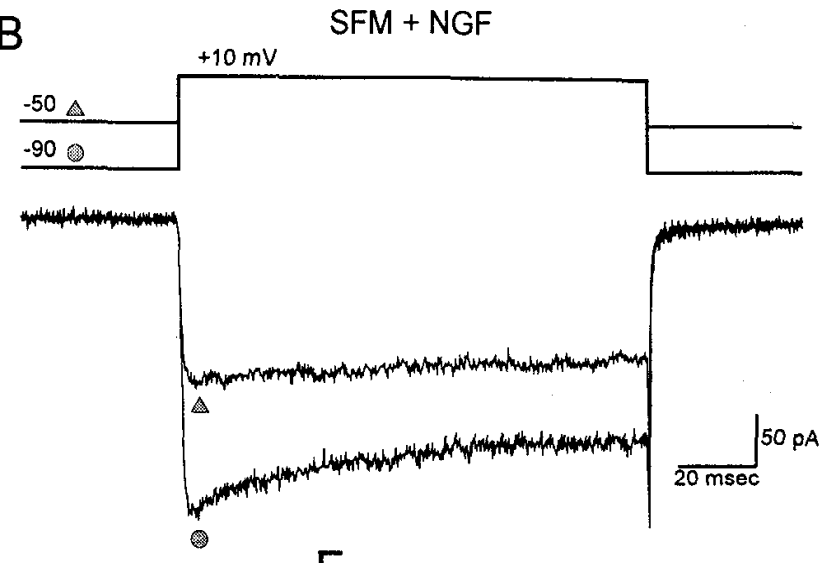

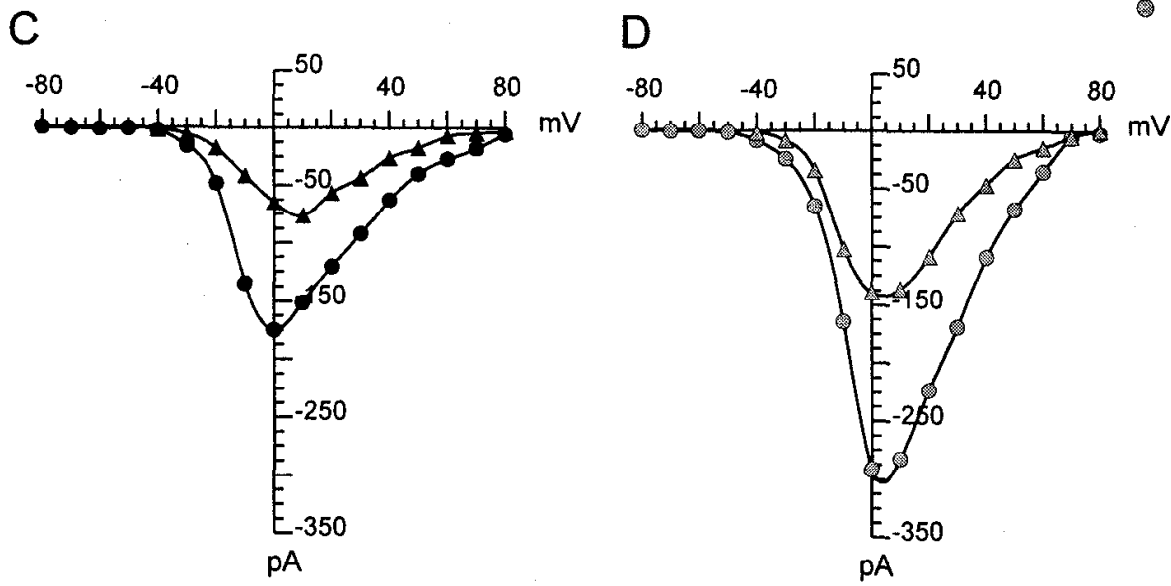

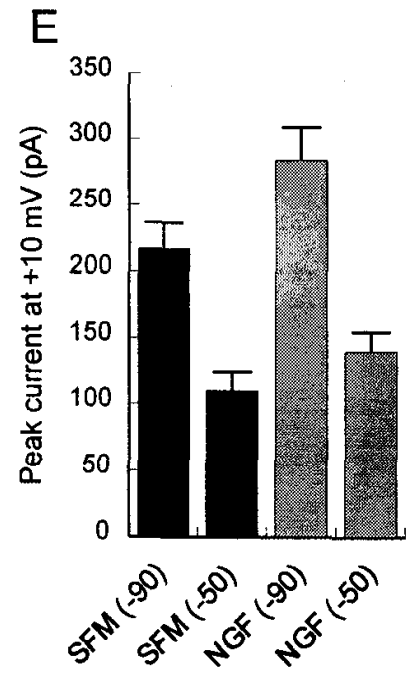

Figure 4. NGF induced an increase in both inactivating and noninactivating $\mathrm{Ca}^{2+}$-channel currents. $A$, Superimposed sweeps comparing the calcium current elicited in response to $+10 \mathrm{mV}$ from holding potentials of -90 (circle) and $-50 \mathrm{mV}$ (triangle). Reduction in the holding potential decreased an inactivating component of current. $B$. Superimposed sweeps from an NGF-treated cell with the same voltage protocol as in $A$. Although the absolute amount of current is increased, the relative proportions of the holding potential-dependent and-independent components were the same as for cells grown in SFM. $C$ and $D$, Current-voltage relationships from SFM and NGF cells, respectively. $E$, Overall amounts of current seen at holding potentials of -90 and $-50 \mathrm{mV}$. The proportional decrease in current after reducing the holding potential was the same for both SFM and NGF cells $(n=30$ cells; $p>0.5$, Student's $t$ test).

tential of $-90 \mathrm{mV}$. For each set of cultures, four to six cells were recorded from a single plating for each condition. Membrane capacitance was also determined for all cells and used as an index of cell size. Cell capacitance was then used to normalize the peak current valucs to control for potential changes in membrane surface area.

When sample sweeps from several different recordings made from sister cultures of serum-free neurons were superimposed, the variation and average amplitude of the $\mathrm{Ca}^{2+}$-channel currents could be seen (Fig. 2A). The average peak current amplitude was $212.5 \pm 26.8 \mathrm{pA}(n=40$ cells $)$. For NGF-treated cells, a similar superposition showed that NGF treatment had resulted in an overall increase in calcium current amplitude to $296.4 \pm$ 25.6 pA ( $n=40$ cells; Fig. $2 B$ ). There was no obvious change in the kinetics of the currents, as the rates of activation and inactivation in NGF-treated cells were similar to that of the serum-free cells.

Calculations of current density indicated that the increased peak $\mathrm{Ca}^{2+}$-channel currents were not due to increased cell size. For NGF-treated cells, the mean calcium current density was $10 \%$ greater than for cells grown in serum-free conditions (Fig. $2 C ; n=8$ sets of cultures). This increase was statistically sig- nificant ( $p<0.01$, Student's $t$ test, two tailed). Based upon measurements of cell capacitance, the membrane area of the NGFtreated and serum-free cells was not significantly different (4.79 $\pm 0.41 \mathrm{pF}$ vs $5.17 \pm 0.21 \mathrm{pF}$ for serum-free and NGF cells, respectively; $p>0.6$ ).

\section{Effects of BDNF}

As with NGF-treatment, basal forebrain cells grown for $4-6 \mathrm{~d}$ in $100 \mathrm{ng} / \mathrm{ml}$ BDNF did not show any major changes in action potential waveform, firing pattern, or morphology. Unlike NGF treatment, however, cells exposed to BDNF failed to show an increase in the magnitude of voltage-gated $\mathrm{Ca}^{2+}$-channel currents (Fig. 3). Comparisons of the responses of sets of cells to $+10 \mathrm{mV}$ voltage pulses showed no difference in peak current amplitude or kinetics of the calcium current $(-225.4 \pm 25.3$ pA vs $-209.2 \pm 17.7$ pA; Fig. $3 A$ vs $3 B ; n=27$ cells). Furthermore, there was not a significant difference in cell capacitance $(5.62 \pm 0.24$ vs $6.14 \pm 0.52 \mathrm{pF}$ for serum-free and BDNF, respectively; $p>0.4$ ) or calcium current density $(38.85 \pm 8.20$ vs $36.24 \pm 5.22 \mathrm{pA} / \mathrm{pF}$ for serum-free and BDNF, respectively; $p>0.6 ; n=5$ sets of cultures) between the two populations of cells (Fig. $3 C$ ). 

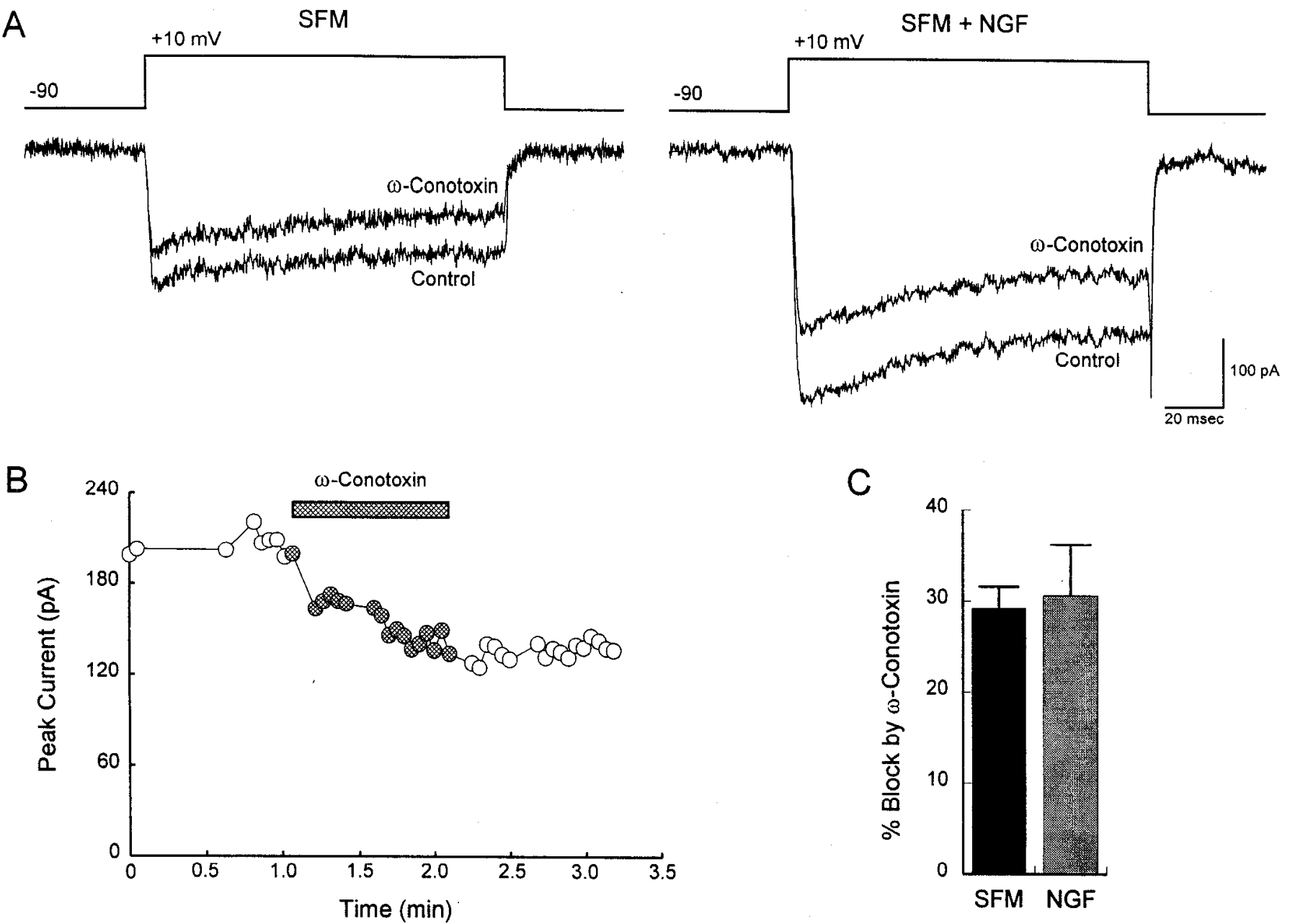

Figure 5. N-Type calcium current was increased by exposure to NGF. A, Sample sweeps showing the amount of calcium current before and after perfusion of $1 \mu \mathrm{M} \omega$-CgTx. The proportional amount of block was similar for both SFM (left) and NGF (right) cells even though the amount of $\omega$-CgTx-sensitive current was increased. $B$, Time course of perfusion showing the irreversible block by $\omega$-CgTx. $C$, Summary of all measurements. The percent block was not significantly different for SFM and NGF neurons ( $n=7$ cells; $p>0.8$, Student's $t$ test).

\section{Separation of calcium current components}

To establish the identity of the calcium currents affected by exposure to NGF, both electrophysiological and pharmacological techniques were employed. Initially, we investigated the sensitivity to changes in holding potential. The magnitude of the L-type current is relatively unaffected by changes in holding potential, whereas the magnitude of the N-type current is substantially reduced at less negative holding potentials. Consequently, we examined the magnitude of calcium current at holding potentials of -90 and $-50 \mathrm{mV}$ to isolate $\mathrm{N}$-type current in the serum-free and NGF-treated cells (Fig. 4).

For both serum-free (Fig. 4A) and NGF-treated cells (Fig. 4B), reducing the holding potential from -90 to $-50 \mathrm{mV}$ caused a reduction in current amplitude and a change in the kinetics. At $-50 \mathrm{mV}$, the remaining current showed very little inactivation, suggesting that it was of the L-type. The holding potential-dependent current showed moderate inactivation, indicating that it was N-type. Examination of the I-V relationship showed that holding potential-dependent current comprised approximately half of the total current (Fig. $4 C, D$ ).

Although the actual amounts of current reduction were different for serum-free and NGF-treated cells (Fig. $4 E$ ), the proportional decrease in current after reducing the holding potential was almost identical for the two conditions $(51.3 \pm 2.1 \%$ vs $46.3 \pm 1.6 \%$ for SFM and NGF, respectively; $n=12 ; p>0.5$ ). These data suggested that both the holding potential-dependent and holding potential-independent components of current were increased by exposure to NGF.

\section{Effects of specific calcium channel antagonists}

To identify the components of the high-threshold calcium current that were affected by NGF treatment pharmacologically, antagonists to specific channel types were used. The effect of NGF on $\mathrm{N}$-type channels was addressed using the specific antagonist $\omega$-conotoxin-GVIA ( $\omega$-CgTx; $1 \mu \mathrm{M}$ ). Examples of the effect of $\omega$-CgTx application for both a control and NGF-treated neuron are shown in Figure $5 \mathrm{~A}$. Both the total current as well as the $\omega$-CgTx-sensitive component of the current were increased by NGF exposure. The time course shown in Figure $5 B$ illustrates the characteristic onset time and irreversible nature of this block. Overall, application of $\omega$ - CgTx blocked $29.2 \pm 2.3 \%$ of the total current for cells grown under serum-free conditions (Fig. $5 C ; n=7$ ). The percentage of $\omega$ - $\mathrm{CgTx}$-sensitive current was not significantly different for neurons grown in the presence of NGF $(30.6 \pm 5.5 \% ; n=5 ; p>0.8)$, indicating that the N-type 

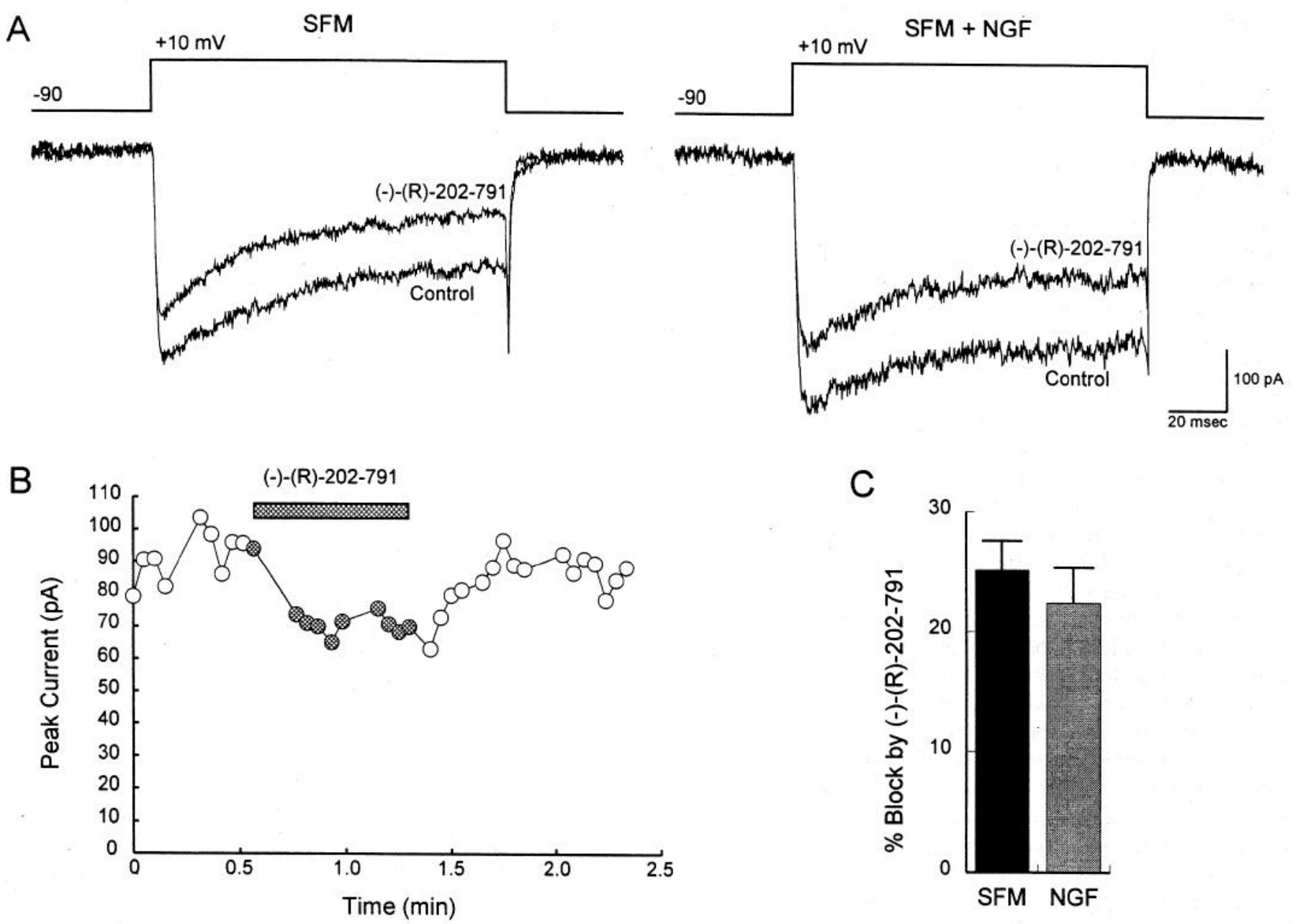

Figure 6. L-Type calcium current was increased by exposure to NGF. $A$, Sample sweeps showing the amount of calcium current before and after perfusion of $2 \mu \mathrm{M}(-)-(R)-202-791$. The proportional amount of block was similar for both SFM (left) and NGF (right) cells even though the amount of DHP-sensitive current increased. $B$, Time course of perfusion showing the reversible block by $(-)-(R)-202-791$. $C$, Summary of all measurements. The percent block was not significantly different for SFM and NGF neurons ( $n=7$ cells; $p>0.5$, Student's $t$ test).

component was increased in proportion to the total current after NGF exposure.

The effect of NGF on L-type channels was also examined by using the specific dihydropyridine (DHP) antagonist (-)-(R)202-791 $(2 \mu \mathrm{M})$. Examples of the effect of application of this drug for both a control and an NGF-treated neuron are shown in Figure $6 \mathrm{~A}$. Similar to the above result, both the total current and the L-type component were increased by NGF treatment. The time course of Figure $6 B$ illustrates the onset time and reversible nature of this block. For neurons grown in SFM alone, superfusion of $(-)-(R)-202-791$ blocked $25.1 \pm 2.5 \%(n=7)$ of the high-threshold calcium current (Fig. $6 C$ ). This was not significantly different from the amount of current blocked in neurons exposed to NGF $(22.4 \pm 2.9 \% ; n=7 ; p>0.5)$, indicating that the L-type component of the recorded current was also increased in proportion to the total current after NGF exposure.

In addition to the N-type and L-type components of the whole-cell calcium current, basal forebrain neurons possessed a DHP-insensitive, $\omega$-CgTx-insensitive component of current. The existence of this component can be inferred from the summed block produced by both the DHP antagonist $(25 \%)$ and $\omega-\mathrm{CgTx}$ $(30 \%)$, which leaves $45 \%$ of the current unaccounted for. Since exposure to NGF increased the magnitude of both L-type and $\mathrm{N}$-type currents, but did not change their proportion of the total current, it follows that the amount of the DHP- and $\omega-\mathrm{CgTx}$ insensitive current must also have increased. If this component of current had not changed, then the proportion of L-type and $\mathrm{N}$-type current would have increased following NGF exposure.

\section{Discussion}

NGF and BDNF affect the survival, process outgrowth, and transmitter metabolism of cells in both the PNS and CNS. In the basal forebrain, neurotransmitter synthesis as well as neuronal survival after injury are regulated by NGF (Hefti et al., 1985; Hefti, 1986; Friedman et al., 1993), while BDNF influences neuronal survival (Friedman et al., 1993). Signal transduction of these trophic effects may involve calcium as an intracellular second messenger.

In the present studies, voltage-gated $\mathrm{Ca}^{2+}$-channel currents were recorded from cultured embryonic basal forebrain neurons. Exposure for 4-6 d to NGF increased the calcium current density in these neurons. This increase reflected changes in both the L-type and N-type components of the whole-cell calcium current, as well as a DHP-insensitive, $\omega$-CgTx-insensitive component of current. This represents a novel effect of NGF on basal 
forebrain neurons, and demonstrates specificity of action within the neurotrophin gene family, since exposure to BDNF had no effect on $\mathrm{Ca}^{2+}$-channel currents.

The mechanism underlying the NGF-induced modulation of calcium conductance in the present studies is not known. Previous studies have reported that NGF does not alter the survival of basal forebrain neurons, nor does it affect neuronal size or morphology under these culture conditions (Hefti et al., 1985; Friedman et al., 1993). In addition, the lack of effect on cell capacitance in the present studies suggests that there is a specific enhancement of the high-threshold calcium conductance, rather than a generalized trophic effect on these cells. There was also no marked change in the current-voltage relationship or the kinetics of the recorded current. This indicates that the increased conductance is most likcly due to an increase in the number of channels per neuron, but modulation of the activity of existing channels may also occur. Single-channel recordings and labeling of specific channel types could be used in future studies to differentiate between these possibilities.

Furthermore, as shown in the present studies, NGF modulated several pharmacologically distinct components of the whole-cell calcium current in basal forebrain neurons. Thus, different trophic effects of NGF may be mediated by calcium entry via particular channels. Recent studies have shown that calcium can activate distinct intracellular signaling pathways, depending on its mode of entry into neurons (Bading et al., 1993). It may therefore be possible to use specific blockers to investigate the roles of different calcium channels in NGF-mediated effects. Nevertheless, the present results suggest that one of the important effects of NGF on basal forebrain neurons may be to enhance calcium entry via voltage-gated channels.

Although the precise role of these calcium channels in the physiology of basal forebrain neurons is not known, calcium influx in other cell types elicits diverse effects. These effects include modulation of gene expression, transmitter release, and membrane excitability, as well as the activation of calcium-dependent protein kinases (Tsien et al., 1988; Sheng and Greenberg, 1990). Calcium also plays a critical role in the survival of many neuronal populations (Koike et al., 1989; Johnson et al., 1992; Murrel and Tolkovsky, 1993). There is some evidence that calcium mediates growth factor actions in other systems. In sympathetic neurons, for example, calcium is involved in the effect of NGF on neurite outgrowth (Rogers and Hendry, 1990). In addition, the ability of NGF to protect hippocampal neurons against hypoglycemic damage involves modulation of calcium currents (Cheng et al., 1993). Calcium is also involved in many types of synaptic plasticity (Tsien et al., 1988), and changes in calcium conductance can regulate neuronal excitability.

Finally, it is not clear whether NGF by itself is sufficient to activate voltage-dependent calcium channels. Although a recent study demonstrated excitatory effects of NGF alone on septal neurons in oculo (Palmer et al., 1993), NGF may also interact with neurotransmitters to increase calcium influx through voltage-dependent calcium channels. In fact, it has been shown that NGF and related neurotrophins can interact with excitatory amino acid transmitters to regulate the survival and neurite outgrowth of cultured Purkinje cells (Cohen-Cory et al., 1991). These types of interactions may also contribute to the trophic and possible neuromodulatory effects of the neurotrophins in the basal forebrain.

\section{References}

Aguayo LG, White G (1992) Effects of nerve growth factor on TTXsensitivity and capsaicin-sensitivity in adult rat sensory neurons. Brain Res 570:61-67.

Bading H, Ginty DD, Greenberg ME (1993) Regulation of gene expression in hippocampal neurons by distinct calcium signaling pathways. Science 260:181-186.

Berninger B, Garcia DE, Inagaki N, Hahnel C, Lindholm D (1993) BDNF and NT-3 induce intracellular $\mathrm{Ca}^{2+}$ elevation in hippocampal neurones. Neuroreport 4:1303-1306.

Caviedes P, Koistinaho J, Ault B, Rapoport SI (1991) Effects of nerve growth factor on electrical membrane properties of cultured dorsal root ganglia neurons from normal and trisomy 21 human fetuses. Brain Res 556:285-291.

Chalazonitis A, Peterson ER, Crain SM (1987) Nerve growth factor regulates the action potential duration of mature sensory neurons. Proc Natl Acad Sci USA 84:289-293.

Cheng B, McMahon DG, Mattson MP (1993) Modulation of calcium current, intracellular calcium levels and cell survival by glucose deprivation and growth factors in hippocampal neurons. Brain Res 607: $275-285$.

Cohen-Cory S, Dreyfus CF, Black IB (1991) NGF and excitatory neurotransmitters regulate survival and morphogenesis of cultured cerebellar Purkinje cells. J Neurosci 11:462-471.

D'Arcangelo G, Halegoua S (1993) A branched signaling pathway for nerve growth factor is revealed by Src-, Ras-, and Raf-mediated gene inductions. Mol Cell Biol 13:3146-3155.

Friedman WJ, Ibanez CF, Hallbook F, Persson H, Cain LD, Dreyfus CF, Black IB (1993) Differential actions of neurotrophins in the locus coeruleus and basal forebrain. Exp Neurol 119:72-78.

Garber SS, Hoshi T, Aldrich RW (1989) Regulation of ionic currents in pheochromocytoma cells by nerve growth factor and dexamethasone. J Neurosci 9:3976-3987.

Greene LA, Tischler AS (1976) Establishment of a noradrenergic clonal line of rat adrenal pheochromocytoma cells which respond to nerve growth factor. Proc Natl Acad Sci USA 73:2424-2428.

Hamill OP, Marty A, Neher E, Sakmann B, Sigworth FJ (1981) Improved patch-clamp techniques for high-resolution current recording from cells and cell-free membrane patches. Pfluegers Arch 391:85100 .

Hefti F (1986) Nerve growth factor promotes survival of septal cholinergic neurons after fimbrial transections. J Neurosci 6:2155-2162.

Hefti F, Hartikka J, Eckenstein F, Gnahn H, Heumann R, Schwah M (1985) Nerve growth factor increases choline acetyltransferase but not survival or fiber outgrowth of cultured fetal septal cholinergic neurons. Neuroscience 14:55-68.

Johnson EM Jr, Koike T, Franklin JL (1992) A calcium set point hypothesis of neuronal dependence on neurotrophic factors. Exp Neurol 115:163-166.

Kalman D, Wong B, Horvai AE, Cline MJ, O'Lague PH (1990) Nerve growth factor acts through cAMP-dependent protein kinase to increase the number of sodium channels in PC12 cells. Neuron 2:355366.

Koike H, Saito H, Matsuki N (1993) Effect of fibroblast growth factors on calcium currents in acutely isolated neuronal cells from rat ventromedial hypothalamus. Neurosci Lett 150:57-60.

Koike T, Martin DP, Johnson EM Jr (1989) Role of $\mathrm{Ca}^{2+}$ channels in the ability of membrane depolarization to prevent neuronal death induced by trophic-factor deprivation: evidence that levels of internal $\mathrm{Ca}^{2+}$ determine nerve growth factor dependence of sympathetic gan glion cells. Proc Natl Acad Sci USA 86:6421-6425.

Levi-Montalcini R, Angeletti PU (1968) Nerve growth factor. Physiol Rev 48:534-569.

Lu B, Yokoyama M, Dreyfus CF, Black IB (1991) NGF gene expression in actively growing brain glia. J Neurosci 11:318-326.

Murrell RD, Tolkovsky AM (1993) Role of voltage-gated $\mathrm{Ca}^{2+}$ channels and intracellular $\mathrm{Ca}^{2+}$ in rat sympathetic neuron survival and function promoted by high $\mathrm{K}^{+}$and cyclic AMP in the presence or absence of NGF. Eur J Neurosci 5:1261-1272.

Nikodijevic B, Guroff G (1991) Nerve growth factor-induced increase in calcium uptake by PC.12 cells. J Neurosci Res 28:192-199.

Omri G, Meiri H (1990) Characterization of sodium currents in mammalian sensory neurons cultured in serum-free defined medium with and without nerve growth factor. J Membr Biol 115:13-29.

Palmer MR, Eriksdotter-Nilsson M, Henschen A, Ebendal T, Olson L 
(1993) Nerve growth factor-induced excitation of selected neurons in the brain which is blocked by a low-affinity receptor antibody. Exp Brain Res 93:226-230.

Plummer MR, Logothetis DE, Hess P (1989) Elementary properties and pharmacological sensitivities of calcium channels in mammalian peripheral neurons. Neuron 2:1453-1463.

Pollock ID, Krempin M, Rudy B (1990) Differential effects of NGF, FGF, EGF, cAMP, and dexamethasone on neurite outgrowth and sodium channel expression in PC12 cells. J Neurosci 10:2626-2637.

Puro DG, Mano T (1991) Modulation of calcium channels in human retinal glial cells by basic fibroblast growth factor: a possible role in retinal pathobiology. J Neurosci 11:1873-1880.

Rogers M, Hendry I (1990) Involvement of dihydropyridine-sensitive calcium channels in nerve growth factor-dependent neurite outgrowth by sympathetic neurons. J Neurosci Res 26:447-454.
Sheng M, Greenberg ME (1990) The regulation and function of $c$-fos and other immediate early genes in the nervous system. Neuron 4:477-485.

Thoenen H, Bandtlow C, Heumann R (1987) The physiological function of nerve growth factor in the central nervous system: comparison with the periphery. Rev Physiol Biochem Pharmacol 109:145-178.

Tsien RW, I ipscombe D, Madison DV, Bley KR, Fox AP (1988) Multiple types of neuronal calcium channels and their selective modulation. Trends Neurosci 11:431-438.

Williams LR, Varon S, Peterson GM, Wictorin K, Fischer W, Bjorklund A, Gage FH (1986) Continuous infusion of nerve growth factor prevents basal forebrain neuronal death after fimbria fornix transection. Proc Natl Acad Sci USA 83:9231-9235. 